\title{
TECHNO: JURNAL PENELITIAN
}

Jurnal homepage: $h$ ttp://ejournal.unkhair.ac.id/index.php/Techno

Volume 08 Nomor 01 Mei 2019 DOI: http:/ /dx.doi.org/10.33387/tk.v8i1.977

\section{MICROALGAE POTENTIAL TO REDUCE DISSOLVED AMONIA CONCENTRATION $\left(\mathrm{NH}_{3}\right)$ ON LIQUID WASTE OF UREA FERTILIZER FACTORY}

\author{
Fadjar Sidiq Hidayahtullah ${ }^{1}$, Agus Hermawan ${ }^{1}$, and Nuni Gofar ${ }^{1}$ \\ 1Specialization in Soil Sciences, Faculty of Agriculture, Sriwijaya University, \\ Jl.Raya Palembang-Prabumulih KM 32 Indralaya, Ogan Ilir \\ Telphone +62821-8667-6002 Fakimile (0711) 580644 \\ Email: fchapuchinno@yahoo.com \\ Manuscript recieved:24-02-2019 Revision Accepted: 01-05-2019
}

\begin{abstract}
The purpose of this research to analyzing the abilities of microalgae from various water treatment processes to improving chemical properties $\left(\mathrm{pH}\right.$, dissolved $\left.\mathrm{NH}_{3}, \mathrm{BOD}, \mathrm{NO}_{3}{ }^{-}\right)$the liquid waste of urea fertilizer factory. The sampling method has used the grab sampling method for a certain period. Microalgae sources are obtained from various water treatment processes and mixed with waste of water at a dose of $300 \mathrm{mg} \mathrm{L}^{-1}$. The results showed the source of microalgae clarifier was significantly different in reducing dissolved ammonia concentration, $\mathrm{pH}$, and nitrate. Based on the results of regression analysis and correlation showed that the microalgae population was partially correlated with $\mathrm{pH}, \mathrm{BOD}$, nitrate, and dissolved ammonia of $1.61 \%, 87.70 \%, 55.38 \%$, and $9.63 \%$. While the concentration of dissolved ammonia significantly affected $\mathrm{pH}, \mathrm{BOD}$, nitrate, and microalgae biomass growth of $84.40 \%$.
\end{abstract}

Keywords: microalgae, water treatment process, dissolved ammonia

\section{INTRODUCTION}

Environmentally friendly technology is one of the efforts made by the government to suppress the pollution of industrial waste directly into the environment. Existing industrial wastes, whether liquid, solid, or gas, must fulfill established quality standards such as the Indonesian National Standard (SNI), so that a treatment must be given to water waste before being discharged into the environment (Salmariza, 2012).

According to Faradilla and Asmi (2011) that industrial waste is one of the sectors that the most of contributing to environmental pollution both to land, a body of water and air. Liquid waste especially in the urea factory is contains high ammonia, which if it is not carried out by certain processing and successfully escapes to the water body, it will damage the water body. For this reason, an effort is needed to treat urea liquid waste which has a high ammonia content.

The urea fertilizer industry produces has very serious damage to the water body ecosystem if it is not managed properly. Urea is a compound that is soluble in water with its chemical formula $\left(\mathrm{NH}_{2}\right)_{2} \mathrm{CO}$, with a high nitrogen content up to $48 \%$. Urea is a compound that is soluble in water with its chemical formula $\left(\mathrm{NH}_{2}\right)_{2} \mathrm{CO}$, with a high nitrogen content up to $48 \%$. Processing of liquid waste with levels of urea and ammonia-nitrogen is one of the problems faced by urea fertilizer plants in Indonesia (Faradilla and Asmi, 2011). 
Until now, there are two treatments commonly used in urea fertilizer plants, namely the aeration process and use of activated sludge in open ponds or collected in large ponds so that ammonia will be release into the air. Both of these methods are not effective for large scale because they have several weaknesses, such as for the use of activated sludge having a set amount of time or period. In the period of the activated sludge that has been exhausted it will be discarded and replaced with a new one. So that the weight of operational costs becomes quite large (Ariyanti, 2010).

The same thing can be seen with the use of the aeration method. In this method, only use aerobic bacteria to increase Dissolve Oxygen (DO) in the waste. That aerobic bacteria can survive and be able to decipher harmful substances. But often the amount of aeration pressure given is not proportional to the volume and area of the waste pool. So that it can be said that the aeration method is not effective because there is no alignment between the volume of the container and the aeration given.

One of biological wastewater treatment technique is by using microalgae. Microalgae are a group of micro-sized plants, have chlorophyll so it is very efficient in capturing the sun and carbon dioxide for photosynthesis. In microalgae biomass contains ingredients such as protein, carbohydrates, fats, and nucleic acids. The percentage of the four components varies depending on the type of algae (Badriyah et al., 2013). One of the advantages of microalgae, namely microalgae is able to utilize urea and dissolved ammonia by degrading it to become a source of hydrogen and as a carbon source for itself. As a result, the high ammonia waste can be controlled and economical because it is continuity.

The ability of microalgae to carry out photosynthesis can be used to decompose high ammonia in these wastes. This is because the microalgae need for nitrogen nutrients can be obtained from urea liquid waste in the form of dissolved ammonia $\left(\mathrm{NH}_{3}\right)$.

In this research we will study the relationship between the functions of microalgae found in several stages of water treatment to decompose high ammonia liquid waste in the urea plant by observing dissolved ammonia levels. So, it can be seen the abilities of these microalgae to reducing dissolved ammonia from liquid waste in the urea factory. The purpose of this research to analyzing the abilities of microalgae from various water treatment process to improving chemical properties $\mathrm{pH}$, dissolved $\mathrm{NH}_{3}, \mathrm{BOD}, \mathrm{NO}_{3^{-}}$) the liquid waste of urea fertilizer factory.

\section{EXPERIMENTAL SECTION}

This research was conducted in one of the fertilizer factories in Indonesia administratively in the area of Palembang City. The analysis was conducted at the Laboratory of Chemical Biology and Soil Fertility, Soil Department, Faculty of Agriculture, Sriwijaya University. Time for conducting research in September and October 2016.

The types of microalgae used are various and come from the water treatment process including flocculation, clarifier, continuous blowdown, and flocculation sludge, which previously have been carried out preliminary tests to proving the presence of microalgae in water treatment process. Then the microalgae biomass was measured by the gravimetric method. Calculation of microalgae biomass was carried out at the beginning of the treatment (day 0 ) and the end of treatment ( $8^{\text {th }}$ day). 
The liquid waste used is liquid waste from a high ammonia urea fertilizer plant. Then, the liquid waste analyzed to determine the characteristics of the waste by referring to the testing of wastewater such as Biochemical Oxygen Demand (BOD), $\mathrm{pH}$, dissolved $\mathrm{NH}_{3}$ concentration, $\mathrm{NO}_{3}{ }^{-}$.

The sampling of waste was carried out on a high ammonia urea waste based in storage tanks. The sampling of waste using stainless steel trunks made randomly. Sampling is done using the grab sampling method (a moment) for a certain period. The sampling is cultivated once at a time needed so that homogeneity, quantity and quality of samples are maintained.

All samples of waste taken are collected first in one container to be homogenized again. Then the collected sample put into each plastic container that has been prepared using a measuring cup of $600 \mathrm{~mL}$ of waste water (assuming the specific gravity of urea wastewater has a high ammonia content $=1 \mathrm{~g} / \mathrm{cm}^{3}$ ). The waste samples for experimental media originating from liquid waste from high ammonia-based urea plants, were taken for experiments in the laboratory at random points. Microalgae sources from various water treatment processes are taken at a depth of $0-10 \mathrm{~cm}$. As a treatment it is a source of microalgae, with a level of flocculation (P.1), clarifier (P.2), continuous blow down (P.3), residual flocculation mud (P.4), and control or without treatment (P.5)

Examples of high ammonia-based urea wastes are made at a concentration of $300 \mathrm{ppm}$ (300 $\mathrm{mg}$ of liquid waste added to 1 liter of water using water treatment) so that $600 \mathrm{mg}$ of liquid waste is added to 2 liters of water using water treatment water placed in a plastic jar. Decomposition of ammonia by microalgae was determined by a spectrophotometric method for analysis of dissolved ammonia $\left(\mathrm{NH}_{3}\right)$. Analysis of dissolved ammonia $\left(\mathrm{NH}_{3}\right)$ is carried out every 2 days for 8 days in field conditions (open space). After sampling, stirring is done.

Previously a preliminary test was conducted using a microscope to observe the presence of microalgae in each water treatment process and the concentration of dissolved ammonia in the source of the microalgae. An example of liquid waste from high ammonia urea was pipetted and a concentration of $300 \mathrm{ppm}$ was made with the addition of treatment. Measured dissolved ammonia concentration after being mixed with microalgae sources after being analyzed put in plastic jars. The quality of waste such as $\mathrm{BOD}, \mathrm{pH}, \mathrm{NO}_{3}^{-}$, especially the dissolved ammonia concentration in the waste was measured after adding microalgae sources and was considered as a zero day observation (H-0).

Analysis of dissolved $\mathrm{NH}_{3}$ was carried out by spectrophotometric method. This method utilizes colors that appear after adding $1 \mathrm{~mL}$ of reagent Nessler to the sample and reads absorbance absorption at a wavelength of $460 \mathrm{~nm}$. Uptake that is read then converted in $\mathrm{mgL}^{-1}$ concentration units. The quality of waste after adding microalgae sources on the eighth day of observation ( $\mathrm{H}-8)$ such as $\mathrm{BOD}, \mathrm{pH}, \mathrm{NO}_{3}{ }^{-}$, especially the concentration of dissolved ammonia in the waste was measured again.

The variables observed consisted of dissolved ammonia concentrations in waste on days 0,2 , $4,6,8$, and 10; the content of $\mathrm{BOD}$, and $\mathrm{NO}_{3}$ - on waste on days 0,4 and 8; the level of acidity of the waste $(\mathrm{pH})$ is measured every day; measurement of biomass and the presence of microalgae before $(\mathrm{H}-0)$ and after $(\mathrm{H}-8)$ adding microalgae sources through gravimetric methods and microscopic observations. 
The effect of the type of microalgae source on the observed variables $\left(\mathrm{NH}_{3}\right.$ dissolved day 0,2 , $4,6,8,10$ days after treatment) was analyzed by $\mathrm{F}$ test and continued with BNJ test. The relationship between microalgae biomass with $\mathrm{pH}, \mathrm{BOD}, \mathrm{NO}_{3}{ }^{-}$, and dissolved $\mathrm{NH}_{3}$ will be analyzed by regression and correlation.

\section{RESULT AND DISCUSSION}

\section{The Value of $\mathrm{pH}$}

Based on Graph 3.1. which illustrates the relationship of $\mathrm{pH}$ values at each microalgae source with the time of observation, the best potential is obtained in the source of microalgae clarifier (P.2). The microalgae source showed a graph of the reduce in $\mathrm{pH}$ value every day compared to other microalgae sources and was able to reduce the $\mathrm{pH}$ value from 8.07 to 7.77 . This decline according to Maharsyah et al. (2013) indicated the use of nitrogen from nutrients in the medium by microalgae cells, namely the use of nitrogen in the form of nitrate and ammonia.

By decreasing the value of dissolved ammonia (as presented in Table 4.1) in liquid waste indirectly it will reduce the acidity of the waste, because ammonia has a weak basic character. With reducing $\mathrm{pH}$, the bacteria that cannot stand alkaline will become active and carry out the process of organism activity. According to Effendi and Rina (2012) that the degree of acidity $(\mathrm{pH})$ is a limiting factor for microalgae life. Most freshwater and marine biota are sensitive to changes in $\mathrm{pH}$. Values with a $\mathrm{pH}$ range of $6.5-8.5$ are suitable for aquatic organisms and are needed for the life of phytoplankton.

In the microalgae source of continuous blow down (P.3), there was an increase on the second day observation (H-2) and again reduced in the fifth day observation (H-5). In line with continuous blow down (P.3), to the rest of the flocculation mud (P.4) increases the $\mathrm{pH}$ value on the first day observation (H-1) and drops the following day but rises again on the fourth day observation (H-4).

The increase experienced by several sources of microalgae in the first and fourth days of this observation, according to Prasetyo and Elizabeth (2006) that the photosynthesis of microalgae is a process of absorption of carbon dioxide dissolved in water resulting in a reduce in $\mathrm{CO}_{2}$ dissolved in water. The reduction in $\mathrm{CO}_{2}$ dissolved in water due to photosynthesis will increase $\mathrm{pH}$. Therefore the rate of photosynthesis will be limited by a reduce in carbon $\left(\mathrm{CO}_{2}\right)$, changes in carbon form in the waters and high $\mathrm{pH}$ values.

\section{Microalgae Biomass}

Based on experiments that have been carried out regarding the measurement of microalgae biomass, researchers used the gravimetric method to obtain weight per unit volume. Solution sourced from every source of microalgae that are filtered using filter paper with semipermeable size hole diamater around $0.65 \mu \mathrm{m}$, so the results of the measurement of biomalgae by the gravimetric method can be seen in Graph 3.2 illustrating the relationship of the value of microalgae biomass growth rate with the gravimetric method at each microalgae source with the time of observation.

From Graph 3.2 which illustrates the relationship of the value of microalgae biomass growth rate with the gravimetric method at each microalgae source with the time of observation, it appears there is an indication of the same pattern between zero day observations $(\mathrm{H}-0)$ and eighth day observation (H-8). At zero day observations (H-0) for the flocculation microalgae 
source (P.1) worth 31 and the clarifier (P.2) worth 19, it has almost the same average. But then the surge in population of continuous blow down (P.3) is 193 and the remainder of the flocculation mud (P.4) is 479. The surges that occur in continuous blow down (P.3) and the rest of the flocculation mud (P.4) are significant compared to flocculation (P.1), clarifier (P.2) and the waste control itself (P.5) which are of value 82 indicates that there are many organic and non-organic particles which are not filtered out and are deposited on semipermeable filter paper.

The size of semipermeable filter paper diameters of only $0.65 \mu \mathrm{m}$ has the potential to hold larger particles such as particles of nitrate, clay, organic and inorganic compounds that have a diameter greater than $0.65 \mu \mathrm{m}$. According to Kawaroe (2011) that microalgae are low-level plants that are 5-30 $\mu \mathrm{m}$ in size and when compared to high-level plants producing vegetable oil through photosynthesis microalgae can do the same process more efficiently, even higher productivity.

In Graph 3.2. there is a reduce in continuous blow down (P.3) and the rest of the flocculation mud (P.4) which is the saturation of the flock which has dropped and settles, so there are many ions both cationies and anions that are absorbed inside. After observing the eighth day $(\mathrm{H}-8)$ compared to zero day $(\mathrm{H}-0)$ where there was a reduce in microalgae biomass value in both sources of continuous blow down microalgae (P.3) and the rest of the flocculation mud (P.4), according to Kawaroe (2011) reduce in the number of microalgae biomass by the gravimetric method in harmony with the reduce in the chemical properties of the solution including BOD, COD, nitrite, sulfate, iron. Indirectly it will impact on the growth of microalgae in it which utilizes contained elements.

Different case with happens to flocculation (P.1) and clarifier (P.2) which increases in the eighth day observation (H-8). Because the solution is still in the form of smooth and floating flock particles, so according to Djunaedi (2015) the flocculation system produces faster deposition of flock particles as a result of an increase in particle size and density of coagulated particles. In line with the statement, according to Ariyanti and Noer (2012) that microalgae cells can form a fairly stable suspension with chemicals that have a negative charge on the surface.
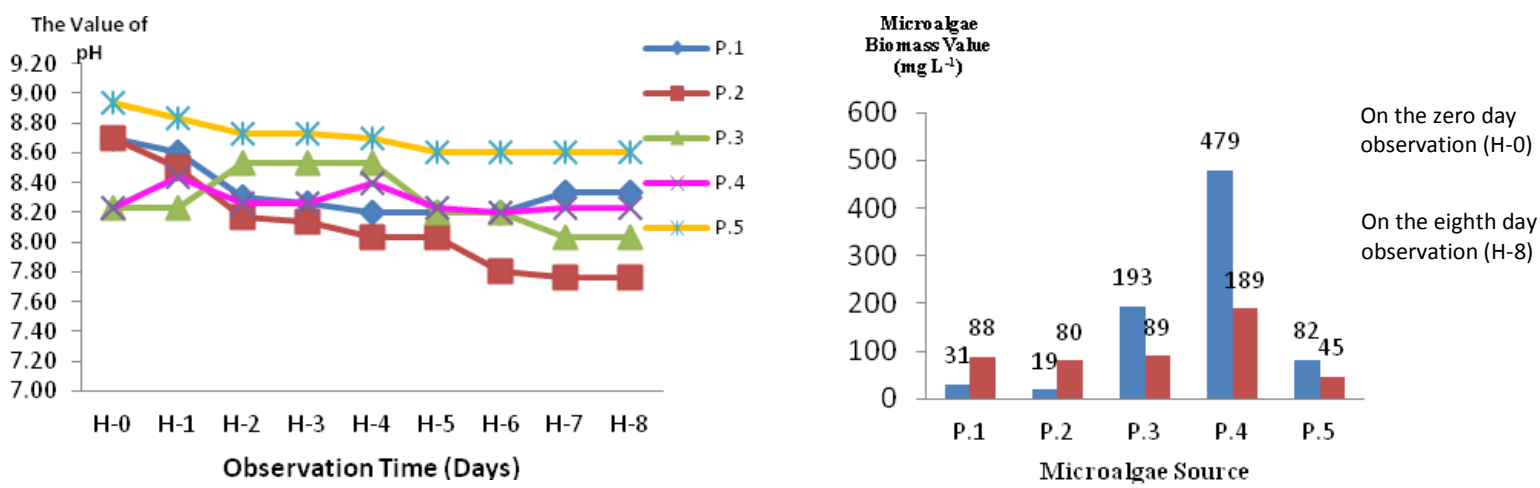
Explanation:

P.1 : Flocculation P.3: Continous Blow Down

P.2: Clarifier P.4: The Residual Flocculation Mud

P.5: Control (Without microalgae Source)

Graph 3.1 The relationship of $\mathrm{pH}$ values in microalgae sources with time of observation

\author{
Explanation: \\ P.1 : Flocculation P.3: Continous Blow Down \\ P.2: Clarifier P.4: The Residual Flocculation Mud \\ P.5: Control (Without microalgae Source)
}

Graph 3.2 The relationship of the value of microalgae biomass growth rate by gravimetric method at each microalgae source with the time of observation

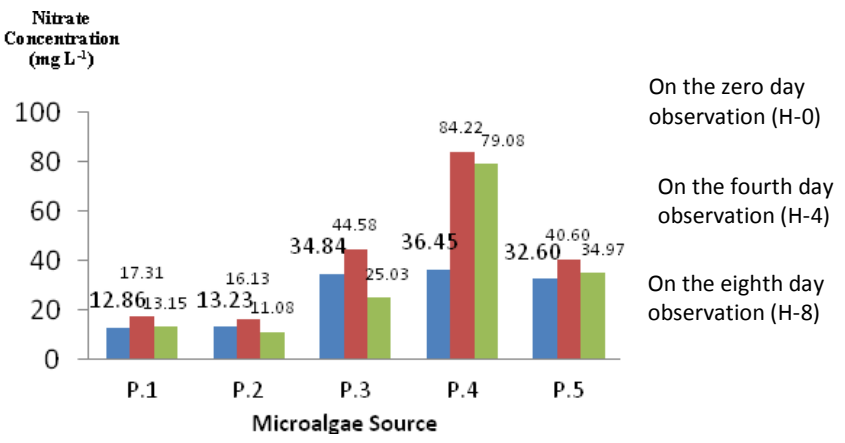

Explanation:

P.1 : Flocculation P.3: Continous Blow Down

P.2: Clarifier P.4: The Residual Flocculation Mud

P.5: Control (Without microalgae Source)

Graph 3.3 The relationship of the concentration of dissolved ammonia $\left(\mathrm{NH}_{3}\right)$ by the time of observation

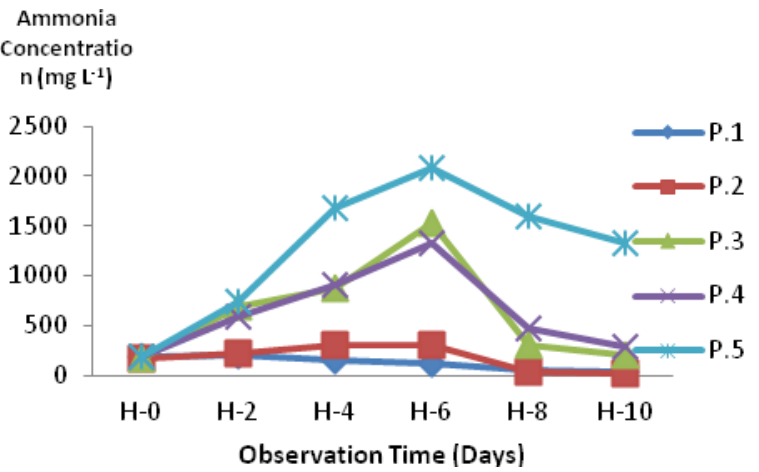

Explanation:

P.1 : Flocculation P.3: Continous Blow Down

P.2: Clarifier P.4: The Residual Flocculation Mud

P.5: Control (Without microalgae Source)

Graph 3.5 The relationship of nitrate concentration in each microalgae source with the time of observation

One species of microalgae, Euglena sp., after the incubation period or application of 2 days, will experience significant growth of microalgae biomass and indirectly after the incubation period entering the fifth day, it will consume nitrogen in this case ammonia. There is a unique thing that happens is that the nitrate concentration will increase first, initially because of the excess dissolved ammonia in the system in the liquid waste. Then only on the sixth day the nitrate incubation will decrease. Nitrogen makes it possible to process nitrification (Mahapatra et al., 2013).

\section{Dissolved Ammonia $\left(\mathrm{NH}_{3}\right)$}

Viewed in Graph 3.3 about the relationship of the concentration of ammonia $\left(\mathrm{NH}_{3}\right)$ dissolved with the time of observation, indicating that the levels of ammonia $\left(\mathrm{NH}_{3}\right)$ dissolved in high ammonia wastewater will initially increase first but the most significant is the source of continuous blow down microalgae (P.3), the rest of the flocculation mud (P.4), 
and control (P.5) on the second day observation (H-2) until the sixth day observation (H-6) then the next will decrease.

The increase in ammonia concentration occurred on the second observation day (H-2) until the sixth day of observation $(\mathrm{H}-6)$ which is the highest point of increasing ammonia $\left(\mathrm{NH}_{3}\right)$ dissolved in the microalgae clarifier source (P.2), continuous blow down (P.3), the rest of the flocculation sludge (P.4), and control (P.5) and return down significantly. According to Faradilla and Asmi (2011) that algae need ammonia for growth, so microalgae must convert to other nitrogen compounds to ammonia before they can use it.

In addition, oxygen produced by photosynthesis in microalgae will be used by microorganisms to decompose organic matter in liquid waste into one of them forming ammonia, which indirectly increases the concentration of ammonia $\left(\mathrm{NH}_{3}\right)$ dissolved in the source of the microalgae, so that it can it is said that there is a synergy between microalgae and microorganisms in liquid waste (Istiyanie, 2011).

In the source of microalgae flocculation (P.1), the increase in ammonia concentration only occurred on the second day $(\mathrm{H}-2)$ of $207,709 \mathrm{mg} \mathrm{L}^{-1}$, and the following day gradually increased. This means that the activity of microorganisms is not as active or more precisely with other sources of microalgae, so that microalgae only increase the composition of nitrogen in the source of this microalgae into a form of dissolved ammonia $\left(\mathrm{NH}_{3}\right)$.

\section{Biochemical Oxygen Demand (BOD)}

In Graph 3.4, the relationship between BOD concentration and time of observation shows that the longer the time, the BOD level in high ammonia liquid waste decreases. According to Valentina and Siti (2013) that greater the BOD number indicates that the degree of waste contamination is greater, and vice versa. BOD trials are one of the important trials to determine the strength or pollutant of wastewater. And also the BOD value does not show the actual amount of organic matter but only measures the relative amount of oxygen needed.

The increase in microalgae flocculation (P.1) and clarifier (P.2) observations on the eighth day $(\mathrm{H}-8)$ shows the activity of microorganisms in it which can increase the value of dissolved oxygen in it. But this increase is not significant and is still below the standards of the Ministry of Environment no. 51 of 1995 which was updated to the Ministry of Environment No. 122 of 2004, namely the maximum BOD for waste $100 \mathrm{mg} \mathrm{L}^{-1}$.

According to Istiyanie (2011) microalgae growth is influenced by environmental factors such as the intensity of sunlight, temperature, $\mathrm{pH}$ and dissolved oxygen. With the increase of microalgae biomass, the amount of oxygen consumed for photosynthesis will increase. Oxygen produced by this photosynthesis process will be used by microorganisms to decompose organic matter present in liquid waste. So that there is a synergy between microalgae and microorganisms in liquid waste. Therefore, the BOD value will decrease.

\section{Nitrate}

In Graph 3.5 about the relationship between nitrate concentration and time of observation shows that nitrate concentration will increase first on the fourth day observation $(\mathrm{H}-4)$ then it will decrease. There is an increase in the fourth day observation ( $\mathrm{H}-4)$ according to Hastuti et al. (2010) that there has been activity of nitrifying and denitrification bacteria in the source of these microalgae. The nitrification process will involve autotrophic ammonia 
oxidizing bacteria, which is a group of bacteria which mainly plays a role in the oxidation process of ammonia to nitrite in the nitrogen cycle, also in the process of decomposition of nitrogen in the source of the microalgae. While the denitrification process is carried out regularly and gradually by several facultative anaerobic bacteria.

The preferred nitrogen source microalgae is in the form of ammonia $\left(\mathrm{NH}_{4}{ }^{+}\right)$and nitrate $\left(\mathrm{NO}_{3}{ }^{-}\right)$. But nitrates will not be consumed by microalgae until the concentration of ammonia $\left(\mathrm{NH}_{3}\right)$ in liquid waste is used up. That's why in the eighth day observation $(\mathrm{H}-8)$ there was a decrease in nitrate concentration compared to previous observations (Istyanie, 2011).

\section{CONCLUSION}

The conclusions obtained from this research are: Microalgae in the clarifier (P.2) decreases dissolved ammonia concentration, nitrate, $\mathrm{pH}$, and significantly increases microalgae biomass compared to microalgae from other sources.

\section{ACKNOWLEDGEMENT}

Thank to my lecturer and my friends (Primastya, Mrs Nuni and Mr Agus) who help and joined the investigation and made documentation in my reasearch.

\section{REFERENCES}

Adawiyah, R. 2011. Diversity of phytoplankton in Lake Tasikardi is related to the content of carbon dioxide and nitrogen. Thesis at Syarif Hidayatullah State Islamic University, Jakarta (Unpublished).

Ariyanti, D. and N.A. Handayani. 2010. Microalgae as a source of renewable biomass: Cultivation and Harvesting Techniques. Ejournal UNDIP 06 (2): 35-40.

Badriyah, L., A. R. Putra, D. Saputra, I. Faiqoh and A. H. Nugraha. 2013. Efficient use of biofloculation techniques in harvesting microalgae Spirullina sp. Species. and Bptryoccus braunii to optimize biodiesel production. Thesis at Bogor Agricultural Institute, Bogor (Unpublished).

Djunaedi, A. 2015. Biomass production of microalgae (Tetraselmis chuii) with different harvesting systems. Tropical Marine Journal. 18 (2): 107-111.

Fadilah, R. and H. D. Ariesyady. 2012. Analysis of the abundance and diversity of microalgae in the stabilization ponds of wastewater treatment plants based on conventional and molecular biological analysis (case study: IPAL Bojongsoang). Thesis at Bandung Institute of Technology, Bandung (Unpublished).

Faradilla, A. and A. R. Juwita. 2011. Utilization of fertilizer factory wastewater with high ammonia levels as microalgae culture media for the acquisition of vegetable oil as biodiesel fuel. Diponegoro University, Semarang (Unpublished).

Hastuti, Y. P. et al. 2010. Profile of traditional farms: soil texture, total N-inorganic and producing bacteria. Indonesian Aquaculture Journal. 9 (2): 119-126.

Hilwatullisan, A. Syakdani, and Husaini. 2014. Lecture Module on Waste Management Engineering. Sriwijaya State Polytechnic, Palembang. 
Istiyanie, D. 2011. Utilization of $\mathrm{CO}_{2}$ emissions from coal power plants in microalgae-based domestic wastewater treatment. Thesis at Postgraduate UI, Depok (Unpublished).

Kawaroe, M. 2011. Cultivation of Schenedesmus sp. in the waste water medium Schenedesmus sp. Biota. 16 (2): 193-199.

Mahapatra, D.M., and H.N. Chamakya. 2013. Euglena sp. as a suitable source of lipids for potential use as a biofuel and sustainable wastewater treatment. J. Appl Phycol DOI 01 (1): 10811-10813.

Maharsyah, T., M. Lutfi, W.A. Nugroho. 2013. Effectiveness of Addition of Growth Bacteria (Azospirillum sp.) Plant in increasing the growth of microalgae (Chlorella sp.) In tofu liquid waste media after anaerobic process. Journal of Tropical Agriculture Engineering and Biosystems. 1 (3): 258-264.

Makarevicience, V., V. Andruleviciute, V. Skorupskaite, and J. Kasperoviciene. 2011. Cultivation of microalgae Chlorella sp. and Scenedesmus sp. as a potentional biofuel feedstock. Environmental Research, Engineering and Management 03 (57): 21-27.

Mulyanto, A., T. Handayani. 2015. Fixation of carbon dioxide emissions by cultivating microalgae using nutrients from the dairy industry's wastewater. Journal of Industrial Research 09 (1): 13-21.

Prasetyo, B. and E. N. Kusumaningrum. 2011. Microalgae and chemical physical conditions of Situ Babakan, Jagakarsa, South Jakarta. In: 2011 FMIPA-UT National Seminar.

Rina, P.A., Philip, and Sumiarsa. 2012. The abundance of several types of microalgae in atoms in the waters of Gumilamo-Magaliho Island, North Halmahera. Journal of Tropical Marine Science and Technology 4 (1): 97-106.

Said, N.I... 2011. Waste water treatment technology with biofilm processes immersed. Journal of Environmental Technology 01 (2): 101-113.

Salmariza. 2012. Utilization of Activated Sludge Mud Waste Industry in Crumb Rubber Industry as Adsorbent. Journal of Industrial Research 6 (2): 175-182.

Valentina, A.E., S.S.Miswadi. 2012. Utilization of water hyacinth charcoal in reducing turbidity, COD, BOD in well water. Indo. J. Chem Sci.2 (2): 84-89. 